\title{
Associations of gender and age groups on the knowledge and use of drug information resources by American pharmacists
}

\author{
Manuel J. CARVAJAL, Kevin A. CLAUSON, Jennifer GERSHMAN, Hyla H. POLEN.
} Received (first version): 7-Jan-2012

Accepted: 15-Jun-2013

\begin{abstract}
*
Objectives: To explore knowledge and use of drug information resources by pharmacists and identify patterns influenced by gender and age-group classification.

Methods: A survey questionnaire was mailed nationwide to 1,000 practitioners working in community $(n=500)$ and hospital $(n=500)$ settings who answer drug information questions as part of their expected job responsibilities. Responses pertaining to drug information resource use and knowledge of different types of drug-related queries, resource media preferences, and perceived adequacy of resources maintained in the pharmacy were analyzed by gender and age group. The $t$ statistic was used to test for significant differences of means and percentages between genders and between age groups. Descriptive statistics were used to characterize other findings.

Results: Gender and age group classification influenced patterns of knowledge and use of drug information resources by pharmacists. They also affected pharmacists' perceptions of the most common types of questions prompting them to consult a drug information reference, as well as the resources consulted. Micromedex, exclusively available in electronic format, was the most commonly consulted resource overall by pharmacists. Lexi-Comp Online was the leading choice by women, preferred over Micromedex, but was not one of the top two resources selected by men.

Conclusion: This study successfully identified the influence of gender and age-group classification in assessing drug information resource knowledge and use of general and specific types of drug-related queries.
\end{abstract}

Keywords: Pharmacists; Drug Information Services; Sex Factors; Age Factors; United States

\footnotetext{
*Manuel J. CARVAJAL. PhD. Professor. College of Pharmacy, Nova Southeastern University. Fort Lauderdale, FL (United States).

Kevin A. CLAUSON. PharmD. Associate Professor. College of Pharmacy, Nova Southeastern University. Fort Lauderdale, FL (United States).

Jennifer GERSHMAN. PharmD. Assistant Professor. College of Pharmacy, Nova Southeastern University. Fort Lauderdale, FL (United States).

Hyla H. POLEN. PharmD. Lead Consultant. Unnatural Language Processing. Jupiter, FL (United States).
}

\author{
ASOCIACIÓN DE GRUPOS DE GÉNERO Y \\ EDAD CON EL CONOCIMIENTO Y USO DE \\ FUENTES DE INFORMACIÓN SOBRE \\ MEDICAMENTOS POR FARMACÉUTICOS \\ ESTADOUNIDENSES
}

RESUMEN
Objetivos: Explorar el conocimiento y el uso de
fuentes de información por farmacéuticos e
identificar los patrones afectados por género y
grupo etario.

Métodos: Se envió un cuestionario por correo a 1000 facultativos de todo el país cuyas funciones en farmacias comunitarias $(n=500)$ y de hospital incluían responder preguntas sobre información de medicamentos. Se analizaron por género y grupo etario las respuestas relativas al uso de fuentes de información y al conocimiento de los diferentes tipos de áreas, preferencias de fuentes e idoneidad percibida de las fuentes. Se utilizó el test t para probar las diferencias de medias y porcentajes entre géneros y grupos etarios. Se usó estadística descriptiva para caracterizar otros hallazgos. Resultados: El género y los grupos etarios afectaron los patrones de conocimiento y uso de fuentes de información sobre medicamentos por farmacéuticos. También afectaron las percepciones de los farmacéuticos sobre los tipos de preguntas más frecuentemente formuladas que les llevaban a consultar fuentes de información sobre medicamentos, así como las fuentes consultadas. Micromedex, sólo disponible en formato electrónico, fue la fuente más consultada por el conjunto de los farmacéuticos. Lexi-Comp Online fue la fuente preferida por las mujeres, seguida de Micromedex, pero no estaba entre las dos fuentes más populares entre los hombres.

Conclusión: Este estudio identificó con éxito la influencia del género y del grupo etario en la evaluación de las fuentes de información sobre medicamentos y el uso en general y específico de búsquedas relativas a medicamentos.

Palabras clave: Farmacéuticos; Servicios de Información sobre Medicamentos; Factores Sexuales; Factores de Edad; Estados Unidos

\section{INTRODUCTION}

Classifying people by gender and age group is a useful technique for discerning patterns of knowledge, attitudes, and behavior, especially in workforce studies. ${ }^{1}$ Men and women often differ in 
their response to identical stimuli, in ways that transcend physical appearance and biological functions, as the communication skills acquired throughout their upbringing, the social roles they play, and the pressures to which they are subject differ. $^{2-4}$ They systematically assign different values to similar labor characteristics. ${ }^{5-7}$ Men are observed to seek jobs in which competition and challenges rewarded by pay, overtime hours, and advancement opportunities abound, regardless of stress or other associated disadvantages, whereas women prefer jobs perceived by them as significant, with supportive supervisors and coworkers and flexible work schedules compatible with work-family balance. $^{8-14}$

Age also is an important modifier. Younger versus older worker comparisons can shed interesting perspectives on the role that work plays in people's lives. Baby boomers, a term applied to workers born between 1946 and 1964, commonly are portrayed in the literature as a generation characterized by solid work-ethic principles, among them commitment to employers, a drive for material success, and a sense of duty. Conversely, generation Xers, comprised of individuals born between 1965 and 1990, exhibit a preference for autonomy and flexible work schedules, are more interested in family and close friends than in material success, organize their lives around the latest gadgets, give priority to personal growth and creativity, and view organizations with cynicism and contempt. ${ }^{15-21}$ Within this context of gender and age variation, a hypothesis has been generated that disparities of views extend to professional attitudes toward, and use of, technology support at work.

Drug information (DI) services in the US have dramatically developed over the past 60 years: they have evolved from the vital part of clinical pharmacy practice to the dispensable element of pharmaceutical care or patient-focused practice. Many DI resources in forms of hard copies and electronic versions have long been used, but those with technologically-mediated clinical decision support are becoming more relevant in recent years for pharmacists and other healthcare professionals. The successful practice of evidence-based health care requires an integration of clinical facilities and expertise with the best research evidence and unique characteristics shown by every patient. Obviously it is impractical, if not impossible, for healthcare practitioners to formulate an answerable question regarding a clinical problem, exhaustively search original research articles and reviews in search of an answer, interpret the implications for the case in point, and appraise the reliability of the findings for every decision made for every patient. Since the body of evidence is constantly evolving according to Irvine, over 6 million articles are published annually - it is imperative that practitioners have convenient access to accurate and timely DI sources. ${ }^{22}$ Furthermore, new drugs and dietary supplements are increasingly available in the market to treat a broad range of diseases and conditions, with accompanying considerations of safety, treatment guidelines, interactions, etc. Thus, the availability and use of reputable DI resources, as well as the process of conducting effective literature searches, are essential for optimal patientcentered care. ${ }^{23-27}$

In response to the growing demand for information, a plethora of DI choices have emerged in print and electronic formats. Personal preferences commonly seem to be the main factor determining practitioners' choice of DI resources used. ${ }^{28}$ These preferences are largely influenced by knowledge and attitudes, which in turn are affected, along with other outcomes, by gender and age group.

The purpose of this study was to explore knowledge and use of DI resources by pharmacists and identify patterns influenced by gender and age-group classification. Specifically, the study sought to assess DI resource use and knowledge of different types of drug-related queries, identify preferences regarding resource media use, evaluate knowledge of individual state DI resource requirements, and measure perceived adequacy of resources maintained in the pharmacy to satisfy these requirements.

\section{METHODS}

The data for the exploration into pharmacists' knowledge and use of DI resources were gathered from responses to a survey questionnaire mailed nationwide to 1,000 practitioners working in community $(n=500)$ and hospital $(n=500)$ settings who answer DI questions as part of their expected job responsibilities. A pilot study was previously conducted to establish face validity of this novel survey instrument, and feedback from the pilot study results was used to modify and improve the original instrument. The text of survey items and their response scale appear in the article Tables. The names and postal addresses of the pharmacists were provided by KM Lists, used previously in workforce and scholarly publications. ${ }^{29-}$ 31 A postage-free return envelope was provided along with the questionnaires; incomplete or unusable returns were not included in the analysis. Respondents remained anonymous at all times, so there was no way to ascertain the identity of nonresponding practitioners. University IRB approval was secured to conduct the study.

The $\mathrm{t}$ statistic was used to test for significant differences of means and percentages between genders and between age groups. Descriptive statistics were used otherwise to characterize empirical results.

\section{RESULTS}

\section{Respondent characteristics}

A total of 114 pharmacists from 37 states returned completed, useable questionnaires. The response rate was $11.4 \%$. Responders' basic demographic characteristics are presented in Table 1. Slightly over one-half ( 56 percent) were men and 52 percent were 50 years of age or younger. Men were disproportionately older, a two-to-one ratio, while women were disproportionately younger by a three- 


\begin{tabular}{|c|c|c|c|c|}
\hline \multirow[b]{2}{*}{ Demographic Characteristic } & \multirow[b]{2}{*}{ Gender } & \multicolumn{3}{|c|}{ Age Group } \\
\hline & & $\begin{array}{c}\text { Both } \\
\text { Age Groups }\end{array}$ & $\begin{array}{l}50 \text { Years } \\
\text { and Younger }\end{array}$ & $\begin{array}{l}\text { Older than } \\
50 \text { Years }\end{array}$ \\
\hline \multirow[t]{3}{*}{ Observations (n) } & Both genders & 114 & 59 & 55 \\
\hline & Male & 64 & 21 & 43 \\
\hline & Female & 50 & 38 & 12 \\
\hline \multirow[t]{3}{*}{ Non-Hispanic White (\%) } & Both genders & $\begin{array}{c}0.87 \\
(0.34)\end{array}$ & $\begin{array}{l}0.92^{8} \\
(0.28)\end{array}$ & $\begin{array}{l}0.82^{\S} \\
(0.39)\end{array}$ \\
\hline & Male & $\begin{array}{l}0.83^{8} \\
(0.38)\end{array}$ & $\begin{array}{c}0.90 \\
(0.29)\end{array}$ & $\begin{array}{c}0.79 \\
(0.41)\end{array}$ \\
\hline & Female & $\begin{array}{l}0.92^{3} \\
(0.27)\end{array}$ & $\begin{array}{c}0.92 \\
(0.27)\end{array}$ & $\begin{array}{c}0.92 \\
(0.28)\end{array}$ \\
\hline \multirow[t]{3}{*}{ Pharm.D. or Ph.D. (\%) } & Both genders & $\begin{array}{c}0.24 \\
(0.42)\end{array}$ & $\begin{array}{l}0.37^{*} \\
(0.48)\end{array}$ & $\begin{array}{l}0.09^{*} \\
(0.29)\end{array}$ \\
\hline & Male & $\begin{array}{l}0.16^{f} \\
(0.36)\end{array}$ & $\begin{array}{c}0.29 \\
(0.45)\end{array}$ & $\begin{array}{c}0.09 \\
(0.29)\end{array}$ \\
\hline & Female & $\begin{array}{l}0.34^{7} \\
(0.47)\end{array}$ & $\begin{array}{c}0.42 \\
(0.49)\end{array}$ & $\begin{array}{c}0.08 \\
(0.28)\end{array}$ \\
\hline \multirow[t]{3}{*}{$\begin{array}{l}\text { Primary work setting: } \\
\text { Retail/community (\%) }\end{array}$} & Both genders & $\begin{array}{c}0.34 \\
(0.47)\end{array}$ & $\begin{array}{c}0.36 \\
(0.48)\end{array}$ & $\begin{array}{c}0.33 \\
(0.47) \\
\end{array}$ \\
\hline & Male & $\begin{array}{c}0.36 \\
(0.48) \\
\end{array}$ & $\begin{array}{c}0.38 \\
(0.49) \\
\end{array}$ & $\begin{array}{c}0.35 \\
(0.48) \\
\end{array}$ \\
\hline & Female & $\begin{array}{c}0.32 \\
(0.47)\end{array}$ & $\begin{array}{c}0.34 \\
(0.47)\end{array}$ & $\begin{array}{c}0.25 \\
(0.43)\end{array}$ \\
\hline \multirow[t]{3}{*}{ Professional experience (years) } & Both genders & $\begin{array}{c}24.2 \\
(12.1)\end{array}$ & $\begin{array}{l}15.5^{*} \\
(6.8)\end{array}$ & $\begin{array}{l}33.4^{*} \\
(9.3)\end{array}$ \\
\hline & Male & $\begin{array}{l}29.5^{*} \\
(11.2)\end{array}$ & $\begin{array}{l}19.4 \\
(6.1)\end{array}$ & $\begin{array}{l}34.4 \\
(9.7)\end{array}$ \\
\hline & Female & $\begin{array}{l}17.4 \\
(9.7)\end{array}$ & $\begin{array}{l}13.4 \\
(6.3)\end{array}$ & $\begin{array}{l}30.2 \\
(7.1)\end{array}$ \\
\hline \multirow[t]{3}{*}{ Average work week (hours) } & Both genders & $\begin{array}{l}35.8 \\
(9.7)\end{array}$ & $\begin{array}{l}36.1 \\
(8.8)\end{array}$ & $\begin{array}{c}35.5 \\
(10.8)\end{array}$ \\
\hline & Male & $\begin{array}{c}36.2 \\
(11.0)\end{array}$ & $\begin{array}{c}36.9 \\
(10.0)\end{array}$ & $\begin{array}{c}35.9 \\
(11.6)\end{array}$ \\
\hline & Female & $\begin{array}{l}35.3 \\
(7.8)\end{array}$ & $\begin{array}{l}35.6 \\
(8.0)\end{array}$ & $\begin{array}{l}34.1 \\
(7.1)\end{array}$ \\
\hline
\end{tabular}

to-one ratio consistent with recent gains in the female workforce. ${ }^{32-35}$

Most pharmacists in the sample were Non-Hispanic White. The percentage of non-minority respondents was greater for women than for men and for younger than older practitioners. These gender and age-group disparities are largely attributable to older male pharmacists, who recorded a substantially lower percentage of non-minorities than the other cells.

Only about one-quarter of practitioners possessed a doctoral degree, and the differences by gender ( $p$ $<0.05)$ and age group $(p<0.01)$ were statistically significant. In response to increasing clinical demands dictated by the patient-centered focus of modern healthcare services within the last ten years, the doctor of pharmacy (Pharm.D.) degree has replaced the traditional baccalaureate degree as the basic requirement for pharmacists entering the profession. Thus, it was not surprising to find that younger and female pharmacists were more likely to have earned a Pharm.D. degree than their older male counterparts.

Respondents of both genders and age groups did not reflect work preferences for retail/community (or other) settings. However, gender differences, and accordingly age-group differences, were apparent when one examined the number of years of professional experience $(p<0.01)$. Within each age group, male pharmacists reported more job experience than female pharmacists, which was consistent with the relatively recent entry of women into the pharmacy workforce, and also accorded with findings by several studies that, compared to men, women experience more interruptions in their careers and show a greater propensity to work part time because they are responsible for more domestic responsibilities. ${ }^{36-39}$ However, the data did not reveal significant differences in average work week by gender or age group.

\section{Empirical evidence}

This section consists of two portions. The first portion focuses on pharmacists' knowledge of, and attitudes toward, print and electronic resource requirements. The second portion analyzes pharmacists' preferences in the use of DI resources. Since many healthcare information sources are available in the market, and patients' health and lives often depend on answering health-related questions correctly, one important indicator is which DI references are most trusted by practitioners under different circumstances and which ones are most appropriate and useful in answering specific patient-care questions. ${ }^{40}$ 


\begin{tabular}{|c|c|c|c|c|}
\hline \multirow[b]{2}{*}{ Response } & \multirow[b]{2}{*}{ Gender } & \multicolumn{3}{|c|}{ Age Group } \\
\hline & & $\begin{array}{c}\text { Both } \\
\text { Age Groups }\end{array}$ & $\begin{array}{l}50 \text { Years } \\
\text { and Younger }\end{array}$ & $\begin{array}{l}\text { Older than } \\
50 \text { Years }\end{array}$ \\
\hline \multirow[t]{3}{*}{$\begin{array}{l}\text { The most frequently used } \mathrm{DI} \text { resource in my } \\
\text { pharmacy is electronic }\end{array}$} & Both genders & $\begin{array}{c}0.71 \\
(0.45)\end{array}$ & $\begin{array}{l}0.78^{\dagger} \\
(0.41)\end{array}$ & $\begin{array}{l}0.64^{\dagger} \\
(0.48)\end{array}$ \\
\hline & Male & $\begin{array}{l}0.59^{*} \\
(0.49)\end{array}$ & $\begin{array}{c}0.67 \\
(0.47)\end{array}$ & $\begin{array}{c}0.56 \\
(0.50)\end{array}$ \\
\hline & Female & $\begin{array}{l}0.86^{*} \\
(0.35)\end{array}$ & $\begin{array}{c}0.84 \\
(0.36)\end{array}$ & $\begin{array}{c}0.92 \\
(0.28)\end{array}$ \\
\hline \multirow{3}{*}{$\begin{array}{l}\text { There are sufficient print references in my } \\
\text { pharmacy to answer DI questions if electronic } \\
\text { resources are not operational }\end{array}$} & Both genders & $\begin{array}{c}0.88 \\
(0.33)\end{array}$ & $\begin{array}{l}0.86 \\
(0.34)\end{array}$ & $\begin{array}{c}0.89 \\
(0.31)\end{array}$ \\
\hline & Male & $\begin{array}{c}0.91 \\
(0.29)\end{array}$ & $\begin{array}{l}0.95 \\
(0.21)\end{array}$ & $\begin{array}{l}0.88 \\
(0.32)\end{array}$ \\
\hline & Female & $\begin{array}{l}0.84 \\
(0.37)\end{array}$ & $\begin{array}{c}0.82 \\
(0.39)\end{array}$ & $\begin{array}{c}0.92 \\
(0.28)\end{array}$ \\
\hline \multirow{3}{*}{$\begin{array}{l}\text { Percentage certainty that I know which DI } \\
\text { resource(s) must be maintained in my pharmacy } \\
\text { in compliance with laws in my state }\end{array}$} & Both genders & $\begin{array}{c}66.1 \\
(35.5)\end{array}$ & $\begin{array}{l}57.0 \\
(38.4)\end{array}$ & $\begin{array}{l}75.9^{*} \\
(32.3)\end{array}$ \\
\hline & Male & $\begin{array}{l}71.7^{\dagger} \\
(33.9)\end{array}$ & $\begin{array}{c}64.0 \\
(36.6)\end{array}$ & $\begin{array}{c}75.5 \\
(33.0)\end{array}$ \\
\hline & Female & $\begin{array}{l}59.0^{\dagger} \\
(37.7)\end{array}$ & $\begin{array}{c}53.2 \\
(39.9)\end{array}$ & $\begin{array}{c}77.5 \\
(31.3)\end{array}$ \\
\hline \multirow{3}{*}{$\begin{array}{l}\text { Percentage certainty that I know which DI } \\
\text { resources must be maintained for all pharmacy } \\
\text { settings and specialties to be in compliance with } \\
\text { laws in my state }\end{array}$} & Both genders & $\begin{array}{c}54.9 \\
(37.1)\end{array}$ & $\begin{array}{l}45.0^{*} \\
(36.9)\end{array}$ & $\begin{array}{l}65.5^{*} \\
(37.7)\end{array}$ \\
\hline & Male & $\begin{array}{l}60.5^{\dagger} \\
(37.9)\end{array}$ & $\begin{array}{c}50.2 \\
(37.1)\end{array}$ & $\begin{array}{c}65.6 \\
(38.7)\end{array}$ \\
\hline & Female & $\begin{array}{l}47.7^{\dagger} \\
(36.5)\end{array}$ & $\begin{array}{c}42.1 \\
(37.3)\end{array}$ & $\begin{array}{c}65.4 \\
(35.3)\end{array}$ \\
\hline \multirow[t]{3}{*}{$\begin{array}{l}\text { My pharmacy has a formal mechanism in place } \\
\text { to keep DI resources current }\end{array}$} & Both genders & $\begin{array}{c}0.52 \\
(0.50)\end{array}$ & $\begin{array}{c}0.48 \\
(0.50)\end{array}$ & $\begin{array}{c}0.56 \\
(0.50)\end{array}$ \\
\hline & Male & $\begin{array}{c}0.52 \\
(0.50)\end{array}$ & $\begin{array}{c}0.38 \\
(0.49)\end{array}$ & $\begin{array}{l}0.58 \\
(0.49)\end{array}$ \\
\hline & Female & $\begin{array}{c}0.52 \\
(0.50)\end{array}$ & $\begin{array}{l}0.53 \\
(0.50)\end{array}$ & $\begin{array}{l}0.50 \\
(0.50)\end{array}$ \\
\hline \multirow{3}{*}{$\begin{array}{l}\text { Electronic resources should be allowed to satisfy } \\
\text { all legal requirements for DI resources kept in a } \\
\text { pharmacy }\end{array}$} & Both genders & $\begin{array}{l}0.54 \\
(0.50)\end{array}$ & $\begin{array}{l}0.52 \\
(0.50)\end{array}$ & $\begin{array}{l}0.54 \\
(0.50)\end{array}$ \\
\hline & Male & $\begin{array}{c}0.52 \\
(0.50)\end{array}$ & $\begin{array}{c}0.67 \\
(0.47)\end{array}$ & $\begin{array}{c}0.54 \\
(0.50)\end{array}$ \\
\hline & Female & $\begin{array}{c}0.52 \\
(0.50)\end{array}$ & $\begin{array}{l}0.45 \\
(0.50)\end{array}$ & $\begin{array}{c}0.58 \\
(0.49)\end{array}$ \\
\hline
\end{tabular}

\section{Knowledge and attitudes}

Seventy percent of pharmacists in the survey responded that the DI resource most frequently used in their pharmacy was electronic (see Table 2). This finding supported the commonly held platitude that, since technology is rapidly advancing and electronic resources offer relatively more timely and readily accessible information, they are increasingly being substituted for print references. ${ }^{23}$ In a similar study, Gettig found that, unlike physicians and nurses, pharmacists preferred electronic over print DI resources. ${ }^{25}$ The frequency of electronic resource preference detected here was significantly greater for women than for men ( $p$ $<0.01$ ) and for younger than older practitioners. However, these comparisons do not necessarily reveal primary individual resource media preferences; they merely reflect proportionately greater use, and perhaps a secondary preference, by female and younger pharmacists to work in sites characterized by greater use of technology or, conversely, be hired by such sites.
A danger associated with relying exclusively on electronic resources is that they may not be available if key elements of technology malfunction. Whenever that happens, patient safety and continuity of operations dictate that print sources be accessible for consultation. This did not seem to be a problem with the vast majority of pharmacists responding to the survey, either by gender or by age group, as nearly nine out of ten respondents believed that there were sufficient print references in their pharmacy to answer DI questions if electronic resources were not operational.

Gender and age group, however, modified patterns of knowledge regarding which DI resources must be maintained in compliance with state law $(p<0.10$ and $p<0.01$, respectively). Compared to female and younger practitioners, male and older pharmacists seemed to possess more knowledge. A similar pattern emerged when pharmacists were asked about DI resources that must be maintained by state law for all pharmacy settings and specialties. 


\begin{tabular}{|c|c|c|c|c|c|c|}
\hline \multirow[t]{2}{*}{ Gender } & \multicolumn{6}{|c|}{ Age Group } \\
\hline & \multicolumn{2}{|c|}{ Both Age Groups } & \multicolumn{2}{|c|}{50 Years and Younger } & \multicolumn{2}{|c|}{ Older than 50 Years } \\
\hline \multirow[t]{3}{*}{$\begin{array}{l}\text { Both } \\
\text { Genders }\end{array}$} & $\begin{array}{l}\text { Adverse drug reactions } \\
\text { and side effects }\end{array}$ & $(69.3 \%)$ & Dosing & $(74.6 \%)$ & $\begin{array}{l}\text { Adverse drug reactions } \\
\text { and side effects }\end{array}$ & $(78.2 \%)$ \\
\hline & Dosing & $(63.2 \%)$ & $\begin{array}{l}\text { Adverse drug reactions } \\
\text { and side effects }\end{array}$ & $(61.0 \%)$ & Compatibility and stability & $(54.5 \%)$ \\
\hline & $\begin{array}{l}\text { Compatibility and } \\
\text { stability }\end{array}$ & $(55.3 \%)$ & Compatibility and stability & $(55.9 \%)$ & Interactions & $(52.7 \%)$ \\
\hline \multirow[t]{3}{*}{ Male } & $\begin{array}{l}\text { Adverse drug reactions } \\
\text { and side effects }\end{array}$ & $(70.3 \%)$ & Dosing & $(71.4 \%)$ & $\begin{array}{l}\text { Adverse drug reactions } \\
\text { and side effects }\end{array}$ & $(76.7 \%)$ \\
\hline & Dosing & $(59.4 \%)$ & $\begin{array}{l}\text { Adverse drug reactions } \\
\text { and side effects }\end{array}$ & $(57.1 \%)$ & Dosing & $(53.5 \%)$ \\
\hline & $\begin{array}{l}\text { Compatibility and } \\
\text { stability }\end{array}$ & $(50.0 \%)$ & Compatibility and stability & $(47.6 \%)$ & Compatibility and stability & $(51.2 \%)$ \\
\hline \multirow[t]{3}{*}{ Female } & $\begin{array}{l}\text { Adverse drug reactions } \\
\text { and side effects }\end{array}$ & $(68.0 \%)$ & Dosing & $(76.3 \%)$ & $\begin{array}{l}\text { Adverse drug reactions } \\
\text { and side effects }\end{array}$ & $(83.3 \%)$ \\
\hline & Dosing & $(68.0 \%)$ & $\begin{array}{l}\text { Adverse drug reactions } \\
\text { and side effects }\end{array}$ & $(63.2 \%)$ & Interactions & $(75.0 \%)$ \\
\hline & $\begin{array}{l}\text { Compatibility and } \\
\text { stability }\end{array}$ & $(62.0 \%)$ & Compatibility and stability & $(60.5 \%)$ & Compatibility and stability & $(66.7 \%)$ \\
\hline
\end{tabular}

Differences were observed between genders ( $p$ $<0.10)$ and age groups $(p<0.01)$.

About one-half of respondents affirmed that their pharmacy had a formal mechanism in place to keep DI resources current by replacing or augmenting print and/or electronic references. This percentage seemed low in view of the importance of DI references toward ensuring the provision of safe and effective pharmacotherapy for patients. Neither differences by gender nor age group were statistically significant, but the percentage reported by younger men was substantially lower compared to the other gender/age-group classifications.

When pharmacists were asked if electronic resources should be allowed to satisfy all legal requirements for DI resources kept in a pharmacy, approximately one-half responded positively. Although it is commonly believed that older workers feel uncomfortable with new forms of technology and are more resistant to apply innovations in their jobs compared to their younger counterparts, the evidence gathered here showed no significant differences in response by gender or age group. ${ }^{41}$

\section{Preferences in the use of DI resources}

In this study pharmacists were asked to identify the three most common types of questions that prompted them to consult a DI reference. "Adverse drug reactions and side effects" was the option most frequently chosen, followed by "dosing", then "compatibility and stability" (Table 3 ). In a recent publication, Schrimsher et al. found that drug interactions, adverse reactions, and over-thecounter (OTC) questions were at the top of the list. ${ }^{42}$ Here men and women showed identical patterns, but differences were observed by age group. While "dosing" was the most frequent question identified by younger pharmacists, it was not one of the top three choices identified by older pharmacists. Instead, questions about "interactions" appeared to gain relevance for practitioners older than 50 years of age, especially women.

Responding pharmacists selected Micromedex, which is available exclusively in electronic format, as the single most commonly consulted DI reference on an overall basis, and the choice was repeated in three of the four gender/age-group classifications (Table 4). This selection lent support to the characterization of Micromedex by Poston et al. as the most updated, unbiased, comprehensive, and definitive information source. ${ }^{40}$ Drug Facts and Comparisons (Facts \& Comparisons), a print resource, was the second most frequently used reference. Two previous similar studies found that Facts \& Comparisons was the reference most available to pharmacists. ${ }^{25,42}$ The Physician's Desk Reference, until recently a popular source of drug use information, was not selected by a single respondent. Interesting patterns emerged when one analyzed use by gender and age group. Lexi-Comp Online was the leading choice of younger and older women alike, preferred over Micromedex, but was not one of the top two resources selected by younger or older men. Women's preference for Lexi-Comp Online made the top two resources chosen by pharmacists 50 years of age and younger being electronic in nature, which was consistent with the view that younger workers tend to prefer options characterized by more advanced technology. ${ }^{25}$

Table 4 also shows the gender and age-group distributions of pharmacists' top two DI resources used for various types of questions encountered. The type of drug-related question being asked was expected to influence which DI sources were consulted. The distribution for adverse drug reactions and side effects, the primary question requiring practitioners to consult a DI reference, was similar to the overall distribution, but responses were quite different for compatibility and stability. Across both genders and age groups, the Handbook on Injectable Drugs was overwhelmingly the top choice for this question type, followed by Micromedex.

A similar pattern was observed for dietary supplement queries, where the Natural Medicines Comprehensive Database, available jointly in print and electronically, ranked as the top choice for both genders and both age groups. Facts and Comparisons: Review of Natural Products also 


\begin{tabular}{|c|c|c|c|c|c|c|c|}
\hline \multirow{7}{*}{$\begin{array}{l}\text { Type of } \\
\text { Question } \\
\text { Most Often } \\
\text { Used Overall }\end{array}$} & \multirow{3}{*}{$\begin{array}{l}\text { Gender } \\
\text { Both } \\
\text { Genders }\end{array}$} & \multicolumn{6}{|c|}{ Age Group } \\
\hline & & \multicolumn{2}{|c|}{ Both Age Groups } & \multicolumn{2}{|c|}{50 Years and Younger } & \multicolumn{2}{|c|}{ Older than 50 Years } \\
\hline & & Micromedex & $(24.6 \%)$ & Micromedex & $(23.7 \%)$ & Micromedex & $(25.5 \%)$ \\
\hline & \multirow[t]{2}{*}{ Male } & Micromedex & $(26.6 \%)$ & Micromedex & $(28.6 \%)$ & Micromedex & $(25.6 \%)$ \\
\hline & & $\begin{array}{l}\text { Facts \& } \\
\text { Comparisons }\end{array}$ & $(20.3 \%)$ & $\begin{array}{l}\text { Facts \& Comparisons } \\
\text { No response }\end{array}$ & $(14.3 \%)$ & Facts \& Comparisons & $(23.3 \%)$ \\
\hline & \multirow[t]{2}{*}{ Female } & Lexi-Comp Online & $(26.0 \%)$ & Lexi-Comp Online & $(26.3 \%)$ & $\begin{array}{l}\text { Lexi-Comp Online } \\
\text { Micromedex }\end{array}$ & $(25.0 \%)$ \\
\hline & & Micromedex & $(22.0 \%)$ & Micromedex & $(21.1 \%)$ & $\begin{array}{l}\text { Clinical } \\
\text { Pharmacology }\end{array}$ & $(25.0 \%)$ \\
\hline \multirow{5}{*}{$\begin{array}{l}\text { Adverse } \\
\text { Drug } \\
\text { Reactions } \\
\text { and Side } \\
\text { Effects }\end{array}$} & \multirow{2}{*}{$\begin{array}{l}\text { Both } \\
\text { Genders }\end{array}$} & Micromedex & $(26.3 \%)$ & Micromedex & $(28.8 \%)$ & Facts \& Comparisons & $(23.6 \%)$ \\
\hline & & $\begin{array}{l}\text { Facts \& } \\
\text { Comparisons }\end{array}$ & $(16.7 \%)$ & Lexi-Comp Online & $(18.6 \%)$ & Micromedex & $(23.6 \%)$ \\
\hline & Male & Micromedex & $(31.2 \%)$ & Micromedex & $(42.9 \%)$ & Facts \& Comparisons & $(25.6 \%)$ \\
\hline & \multirow[t]{2}{*}{ Female } & Lexi-Comp Online & $(26.0 \%)$ & Lexi-Comp Online & $(26.3 \%)$ & $\begin{array}{l}\text { Clinical } \\
\text { Pharmacology }\end{array}$ & $(25.0 \%)$ \\
\hline & & Micromedex & $(20.0 \%)$ & Micromedex & $(21.1 \%)$ & Lexi-Comp Online & $(25.0 \%)$ \\
\hline \multirow[t]{6}{*}{$\begin{array}{l}\text { Compatibility } \\
\text { and Stability }\end{array}$} & \multirow[t]{2}{*}{$\begin{array}{l}\text { Both } \\
\text { Genders }\end{array}$} & $\begin{array}{l}\text { Handbook on Inject. } \\
\text { Drugs }\end{array}$ & $(38.6 \%)$ & $\begin{array}{l}\text { Handbook on Inject. } \\
\text { Drugs }\end{array}$ & $(35.6 \%)$ & $\begin{array}{l}\text { Handbook on Inject. } \\
\text { Drugs }\end{array}$ & $(41.8 \%)$ \\
\hline & & Micromedex & $(15.8 \%)$ & Micromedex & $(16.9 \%)$ & Micromedex & $(14.5 \%)$ \\
\hline & \multirow[t]{2}{*}{ Male } & $\begin{array}{l}\text { Handbook on Inject. } \\
\text { Drugs }\end{array}$ & $(45.3 \%)$ & $\begin{array}{l}\text { Handbook on Inject. } \\
\text { Drugs }\end{array}$ & $(42.9 \%)$ & $\begin{array}{l}\text { Handbook on Inject. } \\
\text { Drugs }\end{array}$ & $(46.5 \%)$ \\
\hline & & Micromedex & $(12.5 \%)$ & Micromedex & $(14.3 \%)$ & $\begin{array}{l}\text { Facts \& Comparisons } \\
\text { Micromedex }\end{array}$ & $(11.6 \%)$ \\
\hline & \multirow[t]{2}{*}{ Female } & $\begin{array}{l}\text { Handbook on Inject. } \\
\text { Drugs }\end{array}$ & $(30.0 \%)$ & $\begin{array}{l}\text { Handbook on Inject. } \\
\text { Drugs }\end{array}$ & $(31.6 \%)$ & $\begin{array}{l}\text { Handbook on Inject. } \\
\text { Drugs }\end{array}$ & $(25.0 \%)$ \\
\hline & & Micromedex & $(20.0 \%)$ & Micromedex & $(18.4 \%)$ & Micromedex & $(25.0 \%)$ \\
\hline \multirow{4}{*}{$\begin{array}{l}\text { Dietary } \\
\text { Supplements }\end{array}$} & \multirow{2}{*}{$\begin{array}{l}\text { Both } \\
\text { Genders }\end{array}$} & NMCD & $(25.4 \%)$ & $N M C D$ & $(32.2 \%)$ & NMCD & $(18.2 \%)$ \\
\hline & & RevNatProd & $(14.9 \%)$ & RevNatProd & $(16.9 \%)$ & No response & $(18.2 \%)$ \\
\hline & Male & NMCD & $(20.3 \%)$ & NMCD & $(28.6 \%)$ & No response & $(20.9 \%)$ \\
\hline & Female & RevNatProd & $(14.0 \%)$ & RevNatProd & $(15.8 \%)$ & GlobalRph.com & $(16.7 \%)$ \\
\hline \multirow[t]{6}{*}{ Dosing } & \multirow{2}{*}{$\begin{array}{l}\text { Both } \\
\text { Genders }\end{array}$} & Micromedex & $(21.9 \%)$ & Micromedex & $(25.4 \%)$ & Facts \& Comparisons & $(18.2 \%)$ \\
\hline & & $\begin{array}{l}\text { Facts \& } \\
\text { Comparisons }\end{array}$ & $(15.8 \%)$ & Lexi-Comp Online & $(16.9 \%)$ & Micromedex & $(18.2 \%)$ \\
\hline & \multirow[t]{2}{*}{ Male } & Micromedex & $(25.0 \%)$ & Micromedex & $(33.3 \%)$ & Facts \& Comparisons & $(20.9 \%)$ \\
\hline & & $\begin{array}{l}\text { Facts \& } \\
\text { Comparisons }\end{array}$ & $(18.8 \%)$ & $\begin{array}{l}\text { Facts \& Comparisons } \\
\text { DI Handbook }\end{array}$ & $(14.3 \%)$ & Micromedex & $(20.9 \%)$ \\
\hline & \multirow[t]{2}{*}{ Female } & Lexi-Comp Online & $(26.0 \%)$ & Lexi-Comp Online & $(26.3 \%)$ & Lexi-Comp Online & $(25.0 \%)$ \\
\hline & & Micromedex & $(18.0 \%)$ & Micromedex & $(21.1 \%)$ & $\begin{array}{l}\text { Clinical } \\
\text { Pharmacology } \\
\text { DI Handbook }\end{array}$ & $(16.7 \%)$ \\
\hline \multirow[t]{6}{*}{ Indications } & \multirow{2}{*}{$\begin{array}{l}\text { Both } \\
\text { Genders }\end{array}$} & Micromedex & $(26.3 \%)$ & Micromedex & $(28.8 \%)$ & Micromedex & $(23.6 \%)$ \\
\hline & & $\begin{array}{l}\text { Clinical } \\
\text { Pharmacology }\end{array}$ & $(14.0 \%)$ & $\begin{array}{l}\text { Clinical Pharmacology } \\
\text { Lexi-Comp Online }\end{array}$ & $(13.6 \%)$ & $\begin{array}{l}\text { Clinical } \\
\text { Pharmacology }\end{array}$ & $(14.5 \%)$ \\
\hline & Male & Micromedex & $(29.7 \%)$ & Micromedex & $(38.1 \%)$ & Micromedex & $(25.6 \%)$ \\
\hline & & $\begin{array}{l}\text { Facts \& } \\
\text { Comparisons }\end{array}$ & $(14.1 \%)$ & Epocrates Rx Premium & $(14.3 \%)$ & Facts \& Comparisons & $(16.3 \%)$ \\
\hline & Female & Lexi-Comp Online & $(22.0 \%)$ & Micromedex & $(23.7 \%)$ & $\begin{array}{l}\text { Clinical } \\
\text { Pharmacology }\end{array}$ & $(25.0 \%)$ \\
\hline & & Micromedex & $(22.0 \%)$ & Lexi-Comp Online & $(21.1 \%)$ & Lexi-Comp Online & $(25.0 \%)$ \\
\hline
\end{tabular}

stood as a popular reference, especially for women and younger pharmacists. Of special interest was the "no-response" option recorded by one-fifth of older men, suggesting that many of them and possibly other practitioners might not possess sufficient knowledge of herbal and dietary supplements to formulate meaningful health-related questions or search for pertinent answers. ${ }^{43,44}$

Most respondents pointed out that they turned to Micromedex when searching for answers pertaining to dosing, indications, and interactions. Facts \& Comparisons was used often by older pharmacists, and Lexi-Comp Online ranked as a favorite of female practitioners. In addition to these three references, Clinical Pharmacology was widely consulted, especially in matters pertaining to indications.

Micromedex was the source of choice for issues dealing with off-label uses, and there was wide variation regarding the selection of other sources. Younger pharmacists showed a preference for Facts \& Comparisons, while women consistently selected Lexi-Comp Online. AHFS Drug Information, available in print as well as electronically, was broadly used by older men. The "no-response" option appeared for men repeatedly, both with off-label uses and OTC products. The number-one resource choice by both genders and 


\begin{tabular}{|c|c|c|c|c|c|c|c|}
\hline \multirow{2}{*}{$\begin{array}{l}\text { Type of } \\
\text { Question }\end{array}$} & \multirow{2}{*}{ Gender } & \multicolumn{6}{|c|}{ Age Group } \\
\hline & & \multicolumn{2}{|c|}{ Both Age Groups } & \multicolumn{2}{|c|}{50 Years and Younger } & \multicolumn{2}{|c|}{ Older than 50 Years } \\
\hline \multirow{6}{*}{$\begin{array}{l}\text { Interaction- } \\
\mathrm{s}\end{array}$} & \multirow{2}{*}{$\begin{array}{l}\text { Both } \\
\text { Genders }\end{array}$} & Micromedex & $(23.7 \%)$ & Micromedex & $(28.8 \%)$ & Micromedex & $(18.2 \%)$ \\
\hline & & Lexi-Comp Online & $(16.7 \%)$ & Lexi-Comp Online & $(18.6 \%)$ & $\begin{array}{l}\text { Clinical Pharmacology } \\
\text { Facts \& Comparisons } \\
\text { Lexi-Comp Online }\end{array}$ & $(14.5 \%)$ \\
\hline & \multirow[t]{2}{*}{ Male } & Micromedex & $(23.4 \%)$ & Micromedex & $(33.3 \%)$ & Micromedex & $(18.6 \%)$ \\
\hline & & Facts \& Comparisons & $(17.2 \%)$ & Facts \& Comparisons & $(19.0 \%)$ & Facts \& Comparisons & $(16.3 \%)$ \\
\hline & \multirow[t]{2}{*}{ Female } & Lexi-Comp Online & $(24.0 \%)$ & Micromedex & $(26.3 \%)$ & Clinical Pharmacology & $(25.0 \%)$ \\
\hline & & Micromedex & $(24.0 \%)$ & Lexi-Comp Online & $(23.7 \%)$ & Lexi-Comp Online & $(25.0 \%)$ \\
\hline \multirow{6}{*}{$\begin{array}{l}\text { Off-label } \\
\text { Uses }\end{array}$} & \multirow{2}{*}{$\begin{array}{l}\text { Both } \\
\text { Genders }\end{array}$} & Micromedex & $(31.6 \%)$ & Micromedex & $(37.3 \%)$ & Micromedex & $(25.5 \%)$ \\
\hline & & Clinical Pharmacology & $(11.4 \%)$ & Facts \& Comparisons & $(15.3 \%)$ & AHFS Drug Information & $(14.5 \%)$ \\
\hline & \multirow[t]{2}{*}{ Male } & Micromedex & $(32.8 \%)$ & Micromedex & $(42.9 \%)$ & Micromedex & $(27.9 \%)$ \\
\hline & & $\begin{array}{l}\text { AHFS Drug Information } \\
\text { Facts \& Comparisons } \\
\text { No response }\end{array}$ & $(10.9 \%)$ & Facts \& Comparisons & $(19.0 \%)$ & AHFS Drug Information & $(16.3 \%)$ \\
\hline & \multirow[t]{2}{*}{ Female } & Micromedex & $(30.0 \%)$ & Micromedex & $(34.2 \%)$ & Clinical Pharmacology & $(25.0 \%)$ \\
\hline & & $\begin{array}{l}\text { Clinical Pharmacology } \\
\text { Lexi-Comp Online }\end{array}$ & $(14.0 \%)$ & $\begin{array}{l}\text { Facts \& Comparisons } \\
\text { Lexi-Comp Online }\end{array}$ & $(13.2 \%)$ & $\begin{array}{l}\text { Lexi-Comp Online } \\
\text { Micromedex }\end{array}$ & $(16.7 \%)$ \\
\hline \multirow{6}{*}{$\begin{array}{l}\text { OTC } \\
\text { Products }\end{array}$} & \multirow{2}{*}{$\begin{array}{l}\text { Both } \\
\text { Genders }\end{array}$} & Facts \& Comparisons & $(28.9 \%)$ & Facts \& Comparisons & $(28.8 \%)$ & Facts \& Comparisons & $(29.1 \%)$ \\
\hline & & $\begin{array}{l}\text { Micromedex } \\
\text { No response }\end{array}$ & $(10.5 \%)$ & Micromedex & $(11.9 \%)$ & No response & $(16.4 \%)$ \\
\hline & \multirow[t]{2}{*}{ Male } & Facts \& Comparisons & $(35.9 \%)$ & Facts \& Comparisons & $(38.1 \%)$ & Facts \& Comparisons & $(34.9 \%)$ \\
\hline & & No response & $(15.6 \%)$ & NonRX Drug Therapy & $(19.0 \%)$ & No response & $(20.9 \%)$ \\
\hline & \multirow[t]{2}{*}{ Female } & Facts \& Comparisons & $(20.0 \%)$ & Facts \& Comparisons & $(23.7 \%)$ & Clinical Pharmacology & $(25.0 \%)$ \\
\hline & & $\begin{array}{l}\text { Facts \& Comparisons } \\
4.0 \\
\text { Lexi-Comp Online }\end{array}$ & $(14.0 \%)$ & $\begin{array}{l}\text { Facts \& Comparisons } \\
4.0\end{array}$ & $(15.8 \%)$ & $\begin{array}{l}\text { Lexi-Comp Online } \\
\text { Micromedex }\end{array}$ & $(16.7 \%)$ \\
\hline \multirow{6}{*}{$\begin{array}{l}\text { Pharmaco- } \\
\text { logy }\end{array}$} & \multirow{2}{*}{$\begin{array}{l}\text { Both } \\
\text { Genders }\end{array}$} & Micromedex & $(24.6 \%)$ & Micromedex & $(25.4 \%)$ & Micromedex & $(23.6 \%)$ \\
\hline & & Clinical Pharmacology & $(16.7 \%)$ & Clinical Pharmacology & $(16.9 \%)$ & Clinical Pharmacology & $(16.4 \%)$ \\
\hline & \multirow[t]{2}{*}{ Male } & Micromedex & $(28.1 \%)$ & Micromedex & $(33.3 \%)$ & Micromedex & $(25.6 \%)$ \\
\hline & & Facts \& Comparisons & $(15.6 \%)$ & $\begin{array}{l}\text { Clinical Pharmacology } \\
\text { Facts \& Comparisons } \\
\text { Package insert }\end{array}$ & $(14.3 \%)$ & Facts \& Comparisons & $(16.3 \%)$ \\
\hline & \multirow[t]{2}{*}{ Female } & Clinical Pharmacology & $(20.0 \%)$ & Micromedex & $(21.1 \%)$ & Clinical Pharmacology & $(25.0 \%)$ \\
\hline & & Micromedex & $(20.0 \%)$ & Clinical Pharmacology & $(18.4 \%)$ & $\begin{array}{l}\text { Lexi-Comp Online } \\
\text { Micromedex }\end{array}$ & $(16.7 \%)$ \\
\hline \multirow{6}{*}{$\begin{array}{l}\text { Pharmaco- } \\
\text { kinetics }\end{array}$} & \multirow{2}{*}{$\begin{array}{l}\text { Both } \\
\text { Genders }\end{array}$} & Micromedex & $(20.2 \%)$ & Micromedex & $(23.7 \%)$ & Micromedex & $(16.4 \%)$ \\
\hline & & Clinical Pharmacology & $(13.2 \%)$ & Lexi-Comp Online & $16.9 \%)$ & $\begin{array}{l}\text { Clinical Pharmacology } \\
\text { GlobalRph.com }\end{array}$ & $(14.5 \%)$ \\
\hline & \multirow[t]{2}{*}{ Male } & Micromedex & $(21.9 \%)$ & Micromedex & $(28.6 \%)$ & Micromedex & $(18.6 \%)$ \\
\hline & & Facts \& Comparisons & $(15.6 \%)$ & Facts \& Comparisons & $(23.8 \%)$ & GlobalRph.com & $(16.3 \%)$ \\
\hline & \multirow[t]{2}{*}{ Female } & Lexi-Comp Online & $(22.0 \%)$ & Lexi-Comp Online & $(21.1 \%)$ & Lexi-Comp Online & $(25.0 \%)$ \\
\hline & & Micromedex & $(18.0 \%)$ & Micromedex & $(21.1 \%)$ & $\begin{array}{l}\text { Clinical Pharmacology } \\
\text { DI Handbook }\end{array}$ & $(16.7 \%)$ \\
\hline Pregnancy & Both & Drugs in Preg. \& Lact. & $(37.7 \%)$ & Drugs in Preg. \& Lact. & $(40.7 \%)$ & Drugs in Preg. \& Lact. & $(34.5 \%)$ \\
\hline $\begin{array}{l}\text { and } \\
\text { Lactation }\end{array}$ & Genders & Facts \& Comparisons & $(11.4 \%)$ & Facts \& Comparisons & $(11.9 \%)$ & $\begin{array}{l}\text { Clinical Pharmacology } \\
\text { Facts \& Comparisons } \\
\text { Micromedex }\end{array}$ & $(10.9 \%)$ \\
\hline & Male & Drugs in Preg. \& Lact. & $(31.2 \%)$ & Drugs in Preg. \& Lact. & $(23.8 \%)$ & Drugs in Preg. \& Lact. & (34.9\%) \\
\hline & & Facts \& Comparisons & $(14.1 \%)$ & Facts \& Comparisons & (19.0\%) & Facts \& Comparisons & $(11.6 \%)$ \\
\hline & Female & Drugs in Preg. \& Lact. & $(46.0 \%)$ & Drugs in Preg. \& Lact. & $(50.0 \%)$ & Drugs in Preg. \& Lact. & (33.3\%) \\
\hline & & Clinical Pharmacology & $(10.0 \%)$ & $\begin{array}{l}\text { Clinical Pharmacology } \\
\text { Facts \& Comparisons } \\
\text { Lexi-Comp Online } \\
\text { Meds \& Mother's Milk }\end{array}$ & $(7.9 \%)$ & $\begin{array}{l}\text { Clinical Pharmacology } \\
\text { Micromedex }\end{array}$ & $(16.7 \%)$ \\
\hline $\begin{array}{l}\text { DI Handboo } \\
\text { Drugs in Pre } \\
\text { Meds \& Mot } \\
\text { NMCD = Na } \\
\text { NonRX Drug } \\
\text { RevNatProd }\end{array}$ & $\begin{array}{l}\text { al Medici } \\
\text { nerapy = } \\
\text { Facts an }\end{array}$ & $\begin{array}{l}\text { dications and Mother's } \\
\text { Comprehensive Datab } \\
\text { nprescription Drug The } \\
\text { omparisons: Review of }\end{array}$ & ation & & & & \\
\hline
\end{tabular}

age groups for addressing OTC product questions was Facts \& Comparisons; Micromedex, Facts \& Comparisons 4.0 (recently changed to Facts \& Comparisons E Answers), Lexi-Comp Online, and Nonprescription Drug Therapy also were selected by respondents to a lesser degree.

Micromedex received the highest ranking by both genders and both age groups when pharmacists needed pharmacology-related information. When comparing choice differences by gender, Facts \& Comparisons was popular with men and Clinical Pharmacology was popular with women. And in matters pertaining to pharmacokinetics, male pharmacists preferred Micromedex, Facts \& Comparisons, and GlobalRph, while female pharmacists leaned toward using Lexi-Comp Online and Clinical Pharmacology. 
The last type of question prompting consultation of a DI resource analyzed in this paper is pregnancy and lactation. Within each gender/age-group classification, Drugs in Pregnancy and Lactation was the top source selected by pharmacists. And, similar to results seen in pharmacology-related queries, there was a distinct polarity in the second choice for pregnancy and lactation issues, with men preferring Facts \& Comparisons and women preferring Clinical Pharmacology.

\section{DISCUSSION}

The findings of this study support the view that electronic DI resources are increasingly being substituted for print references in pharmacists' attempts to integrate clinical facilities and expertise with the best available research evidence and unique individual characteristics in providing optimal patient-centered care. Electronic references are updated with greater frequency and distribution; therefore, they tend to be perceived as more useful, accurate, and timely than print references in formulating questions and providing answers when dealing with direct patient care. Yet, information contained in any reference is only as good as pharmacists' willingness and ability to use that reference within the context of their therapeutic knowledge base. If individual or groups of pharmacists demonstrate a level of comfort and competency with a particular resource, then that resource should be available, when possible. For example, if older practitioners feel more comfortable with print than electronic references, maintaining exclusively an electronic reference may be a poor choice that could lead to suboptimal job performance.

The findings also revealed that gender and agegroup classification influenced patterns of knowledge and use of DI resources by pharmacists. While proportionately more female and younger practitioners worked in establishments in which the most frequently used DI resource was electronic, proportionately more male and older practitioners showed greater knowledge regarding which DI resource(s) must be maintained by their pharmacy in compliance with state law. Beyond these gender and age-group patterns, however, the empirical evidence revealed a nationally widespread absence of certainty by pharmacists regarding which DI resource(s) must be maintained to keep their pharmacy compliant with the laws of their state, both in general and specifically for pharmacy settings and specialties.

Variations by gender and age group were detected in pharmacists' perceptions of the most common types of questions requiring them to consult a DI reference. "Adverse drug reactions and side effects" and "dosing" were the top two choices throughout the sample for both genders and younger practitioners, but "dosing" was not one of the top choices for pharmacists older than 50 years of age. Older pharmacists, especially women, were more concerned with "interaction" queries.
For general questions, Micromedex was by far the most frequently cited DI resource used, although younger and older women alike consulted LexiComp Online more often than Micromedex. Facts \& Comparisons was the second most commonly used reference. Specific settings and specialties elicited different gender and/or age-group patterns of response. Questions dealing with compatibility and stability, dietary supplements, OTC products, pharmacology, and pregnancy and lactation showed fairly homogeneous patterns, while issues pertaining to adverse drug reactions and side effects, dosing, indications, interactions, off-label uses, and pharmacokinetics showed distinct differences in preferences for sources of information by gender and/or age group.

\section{Limitations}

The findings of this study were subject to several limitations. Perhaps the most obvious was participants' limited response. Although adequate for statistical inferences, the sample size was small, especially for younger men and older women. This limitation restricted the options of age-group classifications and made the sample size susceptible to response bias, which might have had an impact upon generalizations about the conclusions. Another limitation was that differences in knowledge and use of DI resources also might respond to classifications not identified here. For example, practice setting, patient population, budget constraints, etc. are likely to affect which resource is available and/or needed, and in what format. Pharmacists ultimately will migrate toward their personal preferences; if they are not familiar or do not feel comfortable with the references available to them in a workplace setting, their capacity for answering selected DI questions may be compromised. Studies such as this one may help decision makers attain a better fit reference or combination based on their workforce, via altering their purchasing decisions and/or launching training initiatives about types of questions and DI resources.

\section{CONCLUSIONS}

This study successfully identified the influence of gender and age-group classification in assessing DI resource knowledge and use of specific types of drug-related queries, identifying preferences regarding resource media use, evaluating knowledge of individual state DI resource requirements, and measuring perceived adequacy of resources maintained in the pharmacy to satisfy these requirements. Further research is needed, broadening the scope of inquiry to include ethnic, geographic, and other workforce classifications, as well as more sophisticated statistical methodologies toward obtaining better answers for DI queries by enhancing the match between available resources and users. This presents an opportunity to reduce the time needed to formulate questions, increase the quality of the answers, and expand practitioners' involvement in the provision of optimal patientcentered care. 


\section{CONFLICT OF INTEREST}

Dr. Clauson received grant support for this study from Elsevier Science, which produces Clinical Pharmacology.

\section{References}

1. Carvajal MJ, Armayor GM, Hardigan PC. Nova Southeastern University College of Pharmacy Monograph Series. Socioeconomic profile of pharmacists in South Florida: who they are, what they do, how much they like it: volume 1. Fort Lauderdale, FL: Nova Southeastern University; 2010.

2. Costa PT, Terracciano A, McCrae RR. Gender differences in personality traits across cultures. J Pers Soc Psychol. 2001;81(2):322-331.

3. Nolen S, Larson J, Grayson C. Explaining the gender difference in depressive symptoms. J Pers Soc Psychol. 1999;77(5):1061-1072.

4. Shauman KA, Noonan MC. Family migration and labor force outcomes: sex differences in occupational context. Soc Forces. 2007;85(4):1735-1764.

5. Bender KA, Donohue SM, Heywood JS. Job satisfaction and gender segregation. Oxf Econ Pap. 2005;57(3):479-496.

6. Kim S. Gender differences in the job satisfaction of public employees: a study of Seoul Metropolitan Government Korea. Sex Roles. 2005;52(9/10):667-681.

7. Konrad AM, Corrigall E, Lieb P, Ritchie JE. Sex differences in job attribute preferences among managers and business students. Group \& Organization Management. 2000; 25(2):108-131.

8. Bender KA, Heywood JS. Job satisfaction of the highly educated: the role of gender, academic tenure, and earnings. Scott J Polit Econ. 2006;53:253-279.

9. Carvajal MJ, Hardigan PC. Pharmacists' inter-gender differences in behavior and opinions: is work input an important mediator? The Internet Journal of Allied Health Sciences and Practice (Internet). 2008;6(2). Accessed at http://ijahsp.nova.edu/articles/vol6num2/pdf/Hardigan.pdf, December 14th 2011.

10. Donohue SM, Heywood JS. Job satisfaction and gender. Int J Manpow. 2004;25(2):211-234.

11. Hersch J. Sex discrimination in the labor market. Foundations and Trends in Microeconomics. 2006;2(4):281-361.

12. Niederle M, Vesterlund L. So women shy away from competition? Do men compete too much? National Bureau of Economic Research, Working Paper 11,474. Q J Econ (Internet). 2007;122(3):1067-1101. Accessed at http://www.nber.org/papers/w11474, December 14th 2011.

13. O'Halloran PL. Gender and racial differences: on-the-job training and payment schemes [dissertation]. [Milwaukee] University of Wisconsin-Milwaukee; 2003. 226 p.

14. Theodossiou I, Vasileiou E. Making the risk of job loss a way of life: does it affect job satisfaction? Research in Economics. 2007;61(2):71-83

15. Jovic $\mathrm{E}$, Wallace JE, Lemaire J. The generation and gender shifts in medicine: an exploratory survey of internal medicine physicians (Internet). BMC Health Serv Res. 2006; 6(55). Accessed at http://www.biomedcentral.com/content/pdf/1472-6963-6-55.pdf, December 14th 2011.

16. Kennedy MM. Managing different generations requires new skills, insightful leadership. Physician Exec. 2003;29(6):2023.

17. Shields MC, Shields MT. Working with generation X physicians. Physician Exec. 2003; 29(6):14-18.

18. Smola KW, Sutton $C D$. Generational differences: revisiting the generational work values for the new millennium. J Organ Behav. 2002;23(4):363-382.

19. Southard G, Lewis J. Building a workplace that recognizes generational diversity. Public Management. 2004;86(3):8-12

20. Wah L. Managing Gen Xers strategically. Manage Rev. 2000;89(3):6.

21. Washburn ER. Are you ready for Generation X? Physician Exec. 2000;26(1):51-57.

22. Irvine JE. Measurement and expression of risk: optimizing decision strategies. Am J Med. 2004;117(5A):2S-7S.

23. Clauson KA, Fass JA, Seamon MJ. Legal requirements for drug information resources maintained by pharmacies. Drug Inf J. 2008;42(6):569-582.

24. Frenzel JE. Using electronic medical records to teach patient-centered care. Am J Pharm Educ. 2010;74(4):1-6.

25. Gettig JP. Drug information availability and preferences of health care professionals in Illinois: a pilot survey study. Drug Inf J. 2008;42(3):263-272.

26. Rheney CC, Byerly WG, Connelly JF. North Carolina physician access to drug information resources. Drug Inf J. 2000;34(1):69-73.

27. Smart S. Evidence-based information online. Practice Nurse. 2008;35(12):31-34

28. Belgado BS, Hatton RC, Doering PL. Evaluation of electronic drug information resources for answering questions received by decentralized pharmacists. Am J Health Syst Pharm. 1997;54(22):2592-2596.

29. Alkhateeb FM, Doucette WR, Ganther-Urmie JM. Influences on consumer spending for herbal products. Res Social Adm Pharm. 2006;2(2):254-265.

30. Pharmacy Manpower Project. (2010). Final Report of the 2009 National Sample Survey of the Pharmacist Workforce to Determine Contemporary Demographic and Practice Characteristics (Prepared by Midwest Pharmacy Workforce Research Consortium). Minneapolis, MN. Accessed at http://www.aacp.org/resources/research/pharmacymanpower/Documents/2009\%20National\%20Pharmacist\%20Workfor ce\%20Survey\%20-\%20FINAL\%20REPORT.pdf, December 15th 2011. 
31. Prochazka AV, Lundahl K, Pearson W, Oboler SK, Anderson RJ. Support of evidence-based guidelines for the annual physical examination: a survey of primary care providers. Arch Intern Med. 2005;165(12):1347-1352.

32. Brown LM, Schommer JC, Mott DA, Gaither CA, Doucette WR, Zgarrick DP, Droege M. Examining gender salary disparities: an analysis of the 2003 multistate salary survey. Res Social Adm Pharm. 2006;2(3):370-387.

33. Gardner SF, Stowe CD. The impact of a gender shift on a profession: women in pharmacy. Forum on Public Policy (Internet). 2006. Accessed at http://forumonpublicpolicy.com/archive07/gardner.pharmacy.pdf, December 15 th 2011.

34. Johnson TJ. Pharmacist workforce in 2020: implications of requiring residency training for practice. Am $\mathrm{J}$ Health Syst Pharm. 2008;65(2):166-170.

35. Kenreigh CA, Wagner LT. The pharmacist shortage: where do we stand? Medscape Pharmacists. 2006;7(1). Accessed at http://www.medscape.com/viewarticle/521115, December 15th 2011.

36. Cunningham M. Influences of gender ideology and housework allocation on women's employment over the life course. Soc Sci Res. 2008;37(1):254-267.

37. Fogli A, Veldkamp L. Nature or nurture? Learning and female labor force dynamics. Federal Reserve Bank of Minneapolis, Research Department Staff Report 386. Accessed at http://www.minneapolisfed.org/research/sr/sr386.pdf, December 15th 2011.

38. Poeschl G, Pinto I, Murias C, Silva A, Ribeiro R. Representations of family practices, belief in sex differences, and sexism. Sex Roles. 2006;55(1-2):111-121.

39. Quesenberry JL, Trauth EM, Morgan AJ. Understanding the "mommy tracks": a framework for analyzing work-family balance in the IT workforce. Inf Res Manage J. 2006;19(2):37-53.

40. Poston RS, Suda KJ, Onita C. Information sources consulted and found useful in answering drug-related questions. EService Journal. 2009;6(3):3-39.

41. Czaja SJ, Sharit J. Age differences in attitudes toward computers. J Gerontol. 1998; 53(5):329-340.

42. Schrimsher RH, Freeman MK, Kendrach M. A survey of drug information resources in Alabama pharmacy facilities. Drug Inf J. 2006;40(1):51-60.

43. Kwan D, Hirschkorn K, Boon H. US and Canadian pharmacists' attitudes, knowledge, and professional practice toward dietary supplements: a systematic review. BMC Complement Altern Med. 2006;6(31):1-10.

44. Lin HW, Pickard S, Mahady GB, Popovich NG. Conceptual development of a measure to assess pharmacists' knowledge of herbal and dietary supplements. Am J Pharm Educ. 2008; 72(3):1-8. 